\title{
Response of frugivorous primates to changes in fruit supply in a northern Amazonian forest
}

\author{
Mourthé, $I{ }^{a *}$ \\ ${ }^{a}$ Núcleo de Pesquisas de Roraima, Instituto Nacional de Pesquisas da Amazônia, \\ Rua Coronel Pinto, 315, Centro, CEP 69301-150, Boa Vista, RR, Brazil \\ *e-mail: imourthe@gmail.com
}

Received: September 13, 2012 - Accepted: April 1, 2013 - Distributed: August 31, 2014

(With 1 figure)

\begin{abstract}
Few attempts have been made to understand how spatiotemporal changes in fruit supply influence frugivores in tropical forests. The marked spatiotemporal variation in fruit supply can affect frugivore abundance and distribution, but studies addressing the effects of this variation on primates are scarce. The present study aimed to investigate how the spatiotemporal distribution of fruits influences the local distribution of three frugivorous primates in the eastern part of the Maracá Ecological Station, a highly seasonal Amazonian rainforest. Specifically, it was hypothesised that primate distribution will track changes in fruit supply, resulting that sites with high fruit availability should be heavily used by primates. During a 1-year study, fruit supply (ground fruit surveys) and primate density (line-transects) were monitored in twelve $2 \mathrm{~km}$-long transects at monthly intervals. Fruit supply varied seasonally, being low during the dry season. The density of Ateles belzebuth was positively related to fruit supply during fruit shortage, but Cebus olivaceus and Alouatta macconnelli did not follow the same pattern. The supply of Sapotaceae fruit was an important component determining local distribution of $A$. belzebuth during the overall fruit shortage. Highly frugivorous primates such as $A$. belzebuth respond to seasonal decline in fruit supply by congregating at places with high fruit supply in this forest, particularly, those with many individuals of species of Sapotaceae. This study underscores the importance of small-scale spatiotemporal changes of fruit supply as a key component of frugivorous primate ecology in highly seasonal environments.
\end{abstract}

Keywords: Amazonia, Maracá Ecological Station, primate distribution, seasonal fruit availability, fruit shortage.

\section{Resposta dos primatas frugívoros à variação na oferta de frutos em uma floresta do norte da Amazônia}

\section{Resumo}

Poucas tentativas foram realizadas para entender como a variação espaço-temporal na oferta de frutos influencia os frugívoros nas florestas tropicais. A variação espaço-temporal dos frutos pode afetar a abundância e distribuição dos frugívoros, mas estudos abordando os efeitos desta variação nos primatas são escassos. Neste estudo, investigou-se como a oferta dos frutos afeta a distribuição local de três espécies de primatas frugívoros na parte leste da Estação Ecológica de Maracá, uma floresta sazonal na Amazônia. Especificamente, testou-se a hipótese de que a distribuição dos primatas acompanharia a variação na oferta de frutos, resultando em uma utilização mais frequente pelos primatas dos locais com maior disponibilidade deste recurso. A disponibilidade de frutos e a densidade dos primatas foram registradas mensalmente ao longo de um ano, em 12 transecções com $2 \mathrm{~km}$ de extensão. A oferta de frutos variou sazonalmente, sendo baixa durante a estação seca. A densidade de Ateles belzebuth se relacionou com a oferta dos frutos durante o período de escassez deste recurso, mas Alouatta macconnelli e Cebus olivaceus não seguiram o mesmo padrão. A oferta dos frutos de Sapotaceae foi um importante determinante da densidade local de A. belzebuth durante o declínio geral de frutos. Em conjunto, estes resultados sugerem que primatas frugívoros tais como $A$. belzebuth respondem aos períodos de escassez de frutos concentrando-se em locais com alta abundância deste recurso nesta floresta, particularmente, onde as Sapotaceae são abundantes. Este estudo ressalta a importância da variação espaço-temporal dos frutos em pequena escala na ecologia dos primatas frugívoros em florestas altamente sazonais.

Palavras-chave: Amazônia, Estação Ecológica de Maracá, distribuição de primatas, disponibilidade sazonal de frutos, escassez de frutos. 


\section{Introduction}

The distribution of food resources in tropical rainforests varies widely in time and space. Fruit supplies in seasonal forests are subjected to marked spatiotemporal variation, being unevenly distributed compared to other potential foods such as leaves or arthropods (Leigh and Windsor, 1996; Stone, 2007). Tropical seasonal forests have relatively long fruit shortages, leading frugivores to face potential energetic deficits, what ultimately drive important responses in their ecology and physiology (Goldizen et al., 1988; Knott, 1998; Ramos Pereira et al., 2010; Sherman and Eason, 1998; Vogel et al., 2012).

Seasonal shift in fruit supply is an outstanding feature of Neotropical forests (Foster, 1996; Terborgh, 1986), but despite the broad recognition that fruit supply varies seasonally, little is known on the effects of this change on frugivorous primates (henceforth primates). The responses of primates to variation in fruiting patterns may include exploiting alternative resources, increasing foraging effort, and home range expansion into marginal habitats (Krishnadas et al., 2011; Stone, 2007; Terborgh, 1983; Wallace, 2005). The distribution of fruit supply is often associated with patterns of within- and between-habitat use (Mendes Pontes, 1997, 1999; Peres, 1994), but only a few attempts have been made to address the extent to which spatiotemporal variation in fruit supply influences primate local density and distribution (Marshall and Leighton, 2006; Milton et al., 2005). Although there is a broad interest in identifying ecological factors limiting primate population in natural habitats, few general hypotheses have been tested, and formal models that explicitly consider the effects of spatiotemporal variation in resource availability have yet to be developed for primates (Marshall and Leighton, 2006; Milton et al., 2005).

In macroecological scales, the density of primates can be primarily determined by total annual fruit production and seasonality - increased density and biomasses follow increasing annual fruit-fall and decreasing seasonality (Hanya et al., 2011; Stevenson, 2001). Seasonal quality of fallback foods may also influence primate densities (Hanya et al., 2006). Studies at local scales also suggested that primate density is associated with density of food (Chapman and Chapman, 1999; Mendes Pontes, 1999; Rovero and Struhsaker, 2007; Symington, 1988), although no study has closely investigated this hypothesis taking seasonality into account. Thus, the question if food density during lean periods is a primary determinant of frugivore local density remains to be tested (Janson and Chapman, 1999; Marshall and Leighton, 2006). Consequently, the understanding of the fine-scale determinants of changes in primate density in response to seasonal changes in fruit supply is still limited.

In this study, the hypothesis that local density of primates living in a highly seasonal forest in northern Amazonia is influenced by changes in fruit distribution was tested. This hypothesis was guided by: (1) most primates rely considerably on fruits, being good models to test the assumption that fruit supply limits their local density and distribution; (2) important aspects of the annual cycles of primates (e.g., reproduction) are in some way associated to seasonal fruiting (Goldizen et al., 1988); (3) previous studies have suggested primates as habitat generalists that shift habitat use in response to fruit availability (Haugaasen and Peres, 2007; Mendes Pontes, 1997; Peres, 1994). Thus if the hypothesis is correct, it is expected that the distribution of primates will track concomitant changes in fruit supply. Whether responses of primates to fruiting shortage vary in accordance to their specific ecological requirements (Clutton-Brock and Harvey, 1977; Terborgh, 1983) was also investigated. While generalist primates are able to shift to alternate non-fruit resources during periods of fruit shortage (Terborgh, 1983), fruit specialists need to invest a high effort searching for this resource (Wallace, 2005). If so, it is predicted that fruit specialist primates track local changes in fruit supply, whereas generalist primates do not.

\section{Material and Methods}

\subsection{Study site and subjects}

The effect of the fluctuations in fruit supply on the distribution of primates was studied during an 11-mo period encompassing the rainy (May-Sep 2009 and Apr 2010) and dry seasons (Oct 2009-Mar 2010) at Maracá Ecological Station $\left(3^{\circ} 21^{\prime} 44^{\prime \prime} \mathrm{N}, 61^{\circ} 26^{\prime} 01^{\prime}\right.$ ' W), hereafter called MES (Figure 1), in the state of Roraima, Brazil. The MES is a $1013 \mathrm{~km}^{2}$ island in the Uraricuera river, and lies on the transition between the Amazonian forests and the Roraima-Rupununi savannas of the Guyana Shield in the northern edge of Brazilian Amazonia. Climatic seasonality varies markedly at MES. Monthly average temperatures are high, frequently exceeding $30^{\circ} \mathrm{C}$. Mean annual rainfall is around $2100 \mathrm{~mm}$, declining sharply in the dry season (Mendes Pontes, 1997). The study site experienced a pronounced drought during this study (cumulative rainfall $=1650 \mathrm{~mm}$ ).

This study was carried out in the undisturbed, upland forest interspersed with small portions of other less extensive habitats in the eastern part of the island (Milliken and Ratter, 1998). Overall, canopy tree assemblage in the study area is dominated by Sapotaceae, Burseraceae, Lecythidaceae, Arecaceae, and Moraceae. Some species such as Peltogyne gracilipes Ducke (Caesalpiniaceae) are distributed in stands, while Pradosia surinamensis (Eyma) T.D.Penn and Ecclinusa guianensis Eyma (Sapotaceae), Tetragastris panamensis (Engl.) Kuntze (Burseraceae), Brosimum lactescens (S.Moore) C.C.Berg. (Moraceae) are widely distributed. Among palms, Attalea maripa (Aubl.) Mart. and Oenocarpus bacaba Mart. are prevalent (Milliken and Ratter, 1998). Overall, fruiting pattern is spatially synchronous across the eastern part of the island showing two distinct annual fruiting peaks (Moskovits, 1985). As in other tropical forests, the study site regularly experiences periods of absolute scarcity of fruits (Mendes Pontes, 2000), when insufficient fruit may be available 


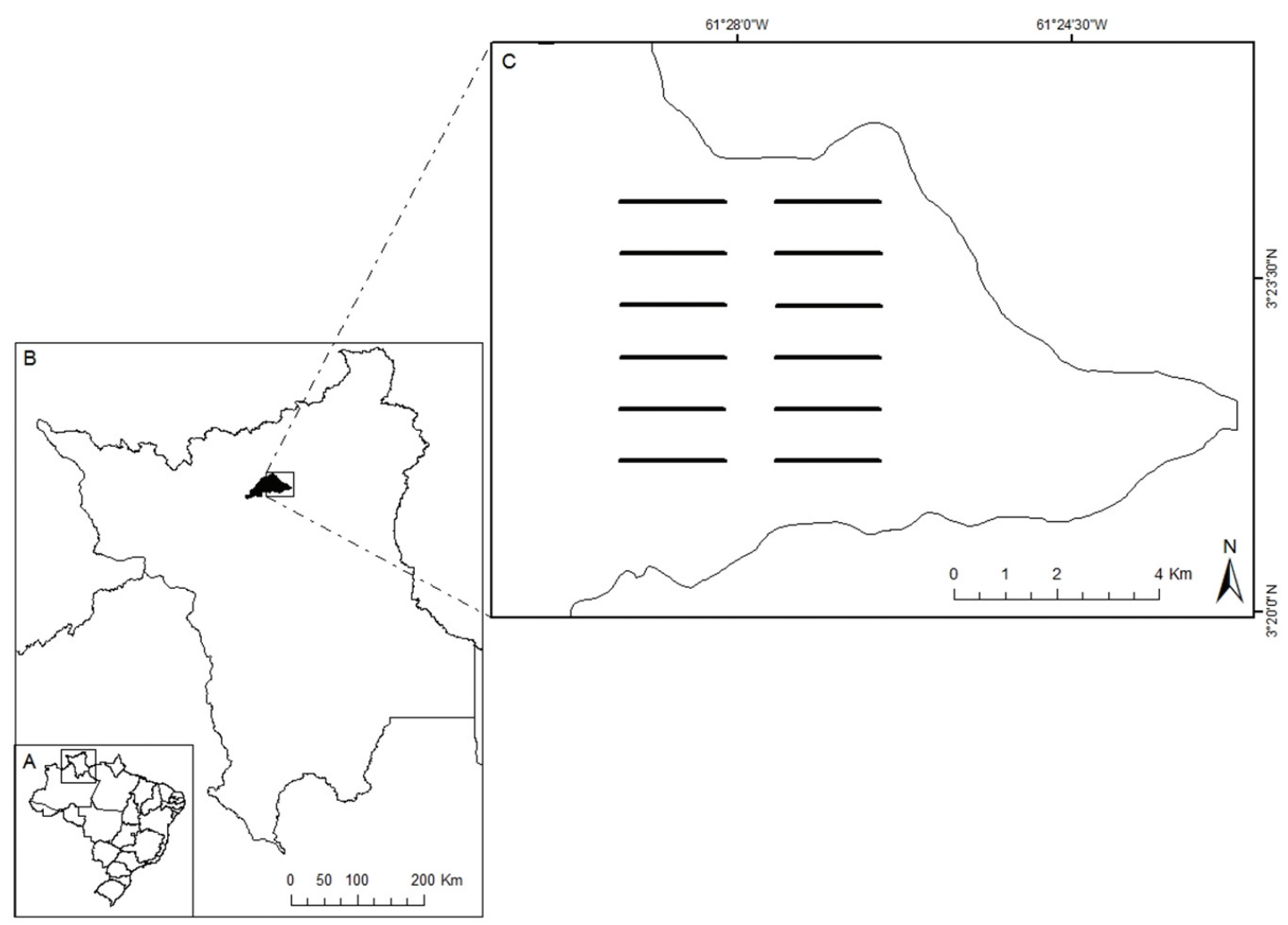

Figure 1. Location of (A) the state of Roraima, (B) Maracá Ecological Station, and (C) the distribution of transects in the eastern part of the island.

to fulfill the metabolic needs of frugivores (Sherman and Eason, 1998; Terborgh, 1986).

Five diurnal primates with varying body sizes and degree of frugivory were previously recorded in the study site (Mendes Pontes, 1999). The largest (ca. $8 \mathrm{~kg}$ ), Ateles belzebuth (É. Geoffroy, 1806) is primarily frugivorous, feeding largely on ripe fruit pulp. This species live in a flexible fission-fusion social system, performing their daily activities in independent troops of varying size and composition (Nunes, 1995). Alouatta macconnelli (Linnaeus, 1766), the second largest primate (ca. $6 \mathrm{~kg}$ ), is a foli-frugivore that spends considerable part of its feeding time on leaves and fruits. The remaining primates are fauni-frugivores: Cebus olivaceus (Schomburgk, 1848) and Sapajus apella (Linnaeus, 1758) are mid-sized (ca. $3 \mathrm{~kg}$ ), and Saimiri sciureus (Linnaeus, 1758), the smallest species (ca. $0.7 \mathrm{~kg}$ ). Although they spend considerable part of their feeding time relying on fruits, these primates feed largely on arthropods during fruit shortages (Terborgh, 1983).

\subsection{Fruit surveys}

To monitor changes in fruit supply, $24 \mathrm{~km}$ of monthly ground surveys along twelve $2000 \times 0.5-\mathrm{m}$, east-west transects located in the eastern part of the island (Figure 1) were conducted. These transects were previously installed in the study area as part of an ongoing Brazilian research programme in biodiversity (PPBio; http://ppbio.inpa. gov.br). Adjacent transects were established 1-km apart, arranged in a $5 \times 5 \mathrm{~km}$ grid. Ground fruit surveys followed protocols previously described elsewhere (Zhang and Wang, 1995). This method provides estimates comparable to other methods often used (e.g., observation of canopies) and has the advantage of avoiding chance concentration effect while capturing spatial variation in fruit production, thus providing a reliable indication of fruit supply fluctuation (Mendes Pontes, 2000; Zhang and Wang, 1995). To avoid inaccurate fruit estimates based on residual counts made under tree crowns, I calculated an index of fruit supply based on the area of transects covered by fallen fruits ('fruit-fall area' [FFA] modified from Leighton and Leighton, 1982). I conservatively defined FFA as a continuous stand of fruits fallen within a fixed area covered by transects just beneath the vertical projection of a particular crown onto the ground; it was calculated by multiplying the length of transect covered by fallen ripe fruits (to the nearest metre) by transect width $(0.5 \mathrm{~m})$. Individual FFAs were summed at species or assemblage levels. For simplicity, I did not take into account the overlap of neighbouring trees of the same species bearing fruits. Where overlap occurred, I considered the multiple trees as a single FFA. Fruit samples were collect and identified to the lowest taxonomical level possible. Fruit and primate surveys were undertaken along the same transects, allowing me to obtain 
reliable estimates of the spatiotemporal distribution of fruit supply, from the perspective of primates (Levey, 1988).

\subsection{Primate surveys}

Replicated line-transect surveys were conducted monthly on the same twelve $2 \mathrm{~km}$-long transects aforementioned (Figure 1) aiming to determine changes in the local density and distribution of primates, which gave me a comparative measure of transect use intensity. Surveys were conducted following a standardised protocol (Peres, 1999). In brief, four consecutive transects were walked at $\sim 1.5 \mathrm{~km} \mathrm{~h}^{-1}$ between $0630-1030 \mathrm{~h}$ and 1300-1700 h, on a daily basis. Transects were walked twice - or in some cases, three times - each month, resulting in a cumulative sampling effort of $587 \mathrm{~km}$ walked (mean: $4.2 \mathrm{~km}$ transect $\mathrm{mo}^{-1}$ ). Primates were recorded upon detection, along with information on date, time, transect, species, and distance along transect. Transects were systematically surveyed in sequence and in alternating directions in consecutive samplings, resulting in a relatively homogeneous distribution of accumulated sampling effort, helping to minimise any confounding spatial effects.

\subsection{Data analysis}

Each transect was considered a sampling unit. Given that number of sightings per transect were low to calculate robust density estimates, primate densities were expressed as sighting rates (group sightings $\mathrm{km}^{-1}$ ). In the case of A. belzebuth that form troops, these encounters may be of troops (Mendes Pontes et al., 2012). Independent analyses were run considering the density of each primate species separately. To evaluate whether fruit supply affected primate distribution, only fruits actually eaten by primates - based on long-term observations - were considered (Rovero and Struhsaker, 2007). Unfortunately, A. belzebuth was the only well-studied primate at MES, and only a set of thirteen fruits (Annonaceae: Duguetia sp.; Arecaceae: Astrocaryum aculeatum G.Mey, Attalea maripa, Mauritia flexuosa L.f.; Burseraceae: Tetragastris panamensis, Trattinnickia rhoifolia Willd.; Chrysobalanaceae: Licania kunthiana Hook.f.; Moraceae: Bagassa guianensis Aubl., Brosimum guianense (Aubl.) Huber ex Ducke, Brosimum lactescens; Sapotaceae: Ecclinusa guianensis, Pouteria hispida Eyma, Pradosia surinamensis) commonly consumed by this primate (Nunes, 1998) and sufficiently sampled during this study were included in the following analyses. Fruit supply was averaged for each transect by season.
Differences in fruit supply between seasons were evaluated using a Wilcoxon signed rank test. The influence of changes in fruit supply on primate local densities was estimated using generalised least squares (GLS) models with Gaussian spatial correlation. GLS is a linear model, whose estimates account for spatial autocorrelation in the residuals, potentially caused by movement patterns of the study subjects or underlying patterns of the landscape (Dormann et al., 2007). How the supply of fruits of two higher taxa (Arecaceae and Sapotaceae) influenced local density of primates during overall fruit shortage was also evaluated by running independent models. Both taxa bear fruit throughout the year and have been suggested as staple resources for primates during overall fruit shortages (Nunes, 1998; Spironello, 2001; Terborgh, 1983). When necessary, the predictive variables were $\log _{(x+1)}$ transformed to improve linearity and homoscedasticity. Observations that were both outlying and had high leverages were removed and models refitted (Fox and Weisberg, 2011). Both results were presented. All analyses were accomplished using R 2.14 (R Development Core Team, 2011). Means were presented \pm SE. The apriori criterion of significance was 0.05 level.

\section{Results}

\subsection{Variation in fruit supply and primate density}

Monthly ripe fruit supply fluctuated during the study, but were relatively low throughout $\left(\mathrm{FFA}=20.4 \pm 4.6 \mathrm{~m}^{2}\right.$, range $=3.0-102.3 \mathrm{~m}^{2}$ ). Fruit supply showed a broad peak in the early rainy season (Apr-Jul: $41.3 \pm 8.6 \mathrm{~m}^{2}$ ) and a narrow peak in the mid dry season (Nov: $33 \pm 6.5 \mathrm{~m}^{2}$ ). Both peaks were accompanied by sharp declines, resulting in low fruit supply during a relatively long period of the year. The highest and lowest fruit supplies were in May $\left(102.3 \pm 20.3 \mathrm{~m}^{2}\right)$ and September $\left(3 \pm 1.2 \mathrm{~m}^{2}\right)$, respectively. Average fruit supply varied significantly between seasons (Wilcoxon signed rank test $\mathrm{V}=70, \mathrm{n}=12, \mathrm{p}=0.01$ ). The abundance of fruits was higher during the rainy season $\left(29.9 \pm 16.4 \mathrm{~m}^{2}\right)$ than in the dry season $\left(13.9 \pm 7.1 \mathrm{~m}^{2}\right)$, hereafter referred to as high fruit season (HFS) and low fruit season (LFS), respectively.

A total of 224 group sightings of four primates (Alouatta macconnelli, Ateles belzebuth, Cebus olivaceus, and Saimiri sciureus) was recorded during this study (Table 1). Sapajus apella was not recorded. The most recorded primate, A. belzebuth, represented $42 \%(\mathrm{n}=94)$ of all sightings. As

Table 1. Sighting rates for four primates estimated in 12 transects in the eastern part of Maracá Ecological Station, northern Amazonia, Brazil.

\begin{tabular}{lccc}
\hline Species & Total no. sightings & $\begin{array}{c}\text { Mean group sighting rate } \\
\mathbf{k m}^{-\mathbf{1}} \mathbf{( \pm \mathbf { S E } )}\end{array}$ & Range \\
\hline Alouatta macconnelli & 43 & $0.07(0.01)$ & $0.04-0.15$ \\
Ateles belzebuth & 94 & $0.16(0.03)$ & $0.02-0.48$ \\
Cebus olivaceus & 79 & $0.13(0.02)$ & $0.04-0.28$ \\
Saimiri sciureus & 8 & $0.01(0.00)$ & $0.00-0.04$ \\
All primates & 224 & $0.38(0.05)$ & $0.22-0.85$ \\
\hline
\end{tabular}


only a few sightings $(\mathrm{n}=8)$ were recorded for S. sciureus, it was excluded from subsequent analyses.

\subsection{Relationship between primates and fruits}

Overall, transect use intensity by primates was not related to density of fruits in transect segments during the HFS. Only A. macconnelli showed a marginally significant relationship with fruit supply during this period. In contrast, the variation in local density of $A$. belzebuth was positively related to ripe fruit supply during the LFS. The local density of Cebus was not related to the abundance of ripe fruits during any period (Table 2). The best predictor of local density of $A$. belzebuth was density of Sapotaceae fruits during the LFS. Fruits of three Sapotaceae species were recorded in all transects during this study. Although also present in all transects, density of palm fruits was not related to variation in primate density. However, the models presented above explained little of the total variance in primate density among transects $(10-20 \%)$ (Table 2$)$.

\section{Discussion}

Fruits are of utmost importance for most primates being their primary source of energy, nutrients and water, but evidence was found that the local distribution of a single, highly frugivorous primate in the seasonal forest at MES is positively influenced, at least in part, by the density of a selected set of fruits commonly consumed. Highly frugivorous primates such as $A$. belzebuth respond to spatiotemporal changes in fruit supply during fruit shortage concentrating themselves in areas with high fruit supply.

As in other Neotropical sites (Foster, 1996; Haugaasen and Peres, 2007; Levey, 1988; van Schaik et al., 1993), although produced all year, fruit supply fluctuates considerably in time and space at MES, resulting in reduced fruit availability during the dry season. Although the study period had been relatively drier than previous years, the overall fruiting pattern recorded resembles that previously described (Mendes Pontes, 2000; Moskovits, 1985).

Relatively large fruit supplies are followed by sharp declines at MES, resulting in little fruit available during relatively long periods (Mendes Pontes, 2000; Nunes, 1998; this study). When food is scarce, animals may invest more time searching for it in more profitable sites (Charnov, 1976), often revisiting those where the renewal rate of food is greater (Krishnadas et al., 2011; Vedder, 1984), as would appear to be the case in the eastern part of MES. Changes in $A$. belzebuth distribution among different areas in the forest suggest a readjustment through local movements (Mendes Pontes, 1997, 1999). The distribution of this primate may be concentrated in the limited areas of most favourable habitats (Mendes Pontes et al., 2012), probably mediated by food resources. Under fruit shortages, primates seem to track changes in fruit supply, often foraging on particular areas where fruits abound (e.g., Ahumada et al., 1998; Krishnadas et al., 2011; Spironello, 2001; Stone, 2007). Site fidelity is related to the presence of sufficient food in the area in which foraging occurs (Fleming and Heithaus, 1986). Optimal foraging studies suggest that animals allocate the greatest amount of time foraging in areas of highest food density and progressively less time in worse areas; a behaviour consistent with a long-term adaptation to environmental fluctuations in food supply (Charnov, 1976; Pyke et al., 1977). While testing optimal foraging assumptions was not an objective of this study, it is likely that $A$. belzebuth optimise their foraging effort in fruit-rich areas during fruit shortages, in this seasonal forest.

Table 2. Results of the generalised least squares models showing the relationship between the density of primates and fruit supply estimated along 12 transects at Maracá Ecological Station, Roraima, Brazil. Bold statistics show significant relationships.

\begin{tabular}{|c|c|c|c|c|c|c|}
\hline \multirow{2}{*}{ Response/predictive variables* } & \multicolumn{3}{|c|}{ Complete model } & \multicolumn{3}{|c|}{ Reduced model** } \\
\hline & $\mathbf{F}_{[1,10]}$ & $\mathbf{r}^{2}$ & $\mathbf{p}$ & $\mathbf{F}_{[1,9]}$ & $\mathbf{r}^{2}$ & $\mathbf{p}$ \\
\hline \multicolumn{7}{|l|}{ Density of A. macconnelli } \\
\hline FFA (LFS) & 0.15 & 0.15 & 0.148 & 0.00 & 0.00 & 0.947 \\
\hline FFA (HFS) & 1.72 & 0.05 & 0.219 & 5.43 & 0.10 & 0.045 \\
\hline FFA Sapotaceae (LFS) & 2.05 & 0.13 & 0.183 & 0.57 & 0.05 & 0.471 \\
\hline $\log _{(x+1)}$ FFA Palms (LFS) & 0.16 & 0.01 & 0.701 & 0.41 & 0.04 & 0.538 \\
\hline \multicolumn{7}{|l|}{ Density of A. belzebuth } \\
\hline $\log _{(x+1)}$ FFA (LFS) & 4.59 & 0.18 & 0.058 & 6.43 & 0.18 & 0.032 \\
\hline $\log _{(x+1)}$ FFA (HFS) & 0.13 & 0.01 & 0.729 & 0.70 & 0.03 & 0.423 \\
\hline $\log _{(x+1)}$ FFA Sapotaceae (LFS) & 3.16 & 0.14 & 0.106 & 8.16 & 0.20 & 0.019 \\
\hline $\log _{(x+1)}$ FFA Palms (LFS) & 0.03 & 0.00 & 0.862 & 1.89 & 0.08 & 0.202 \\
\hline \multicolumn{7}{|l|}{ Density of C. olivaceus } \\
\hline $\log _{(x+1)}$ FFA (LFS) & 0.35 & 0.02 & 0.568 & 0.07 & 0.00 & 0.795 \\
\hline $\log _{(x+1)}$ FFA (HFS) & 0.44 & 0.01 & 0.521 & - & - & - \\
\hline $\log _{(x+1)}$ FFA Sapotaceae (LFS) & 0.68 & 0.03 & 0.428 & - & - & - \\
\hline FFA Palms (LFS) & 1.17 & 0.05 & 0.304 & - & - & - \\
\hline
\end{tabular}

*FFA = fruit fall area, HFS = high fruit season, LFS = low fruit season; **Model without influential points. See methods for details. 
In general, changes in local distribution of primates in response to changes in fruit density during HFS (with exception for Alouatta macconnelli) were not detected. This may indicate that fruit supply during this period is likely to meet (or even exceeds) frugivore needs (Sherman and Eason, 1998). During HFS, a number of abundant and important fruits can be found everywhere throughout the eastern part of MES (Milliken and Ratter, 1998). Therefore, primates may not need to track fruit supply during this period.

Fruits of the Sapotaceae are high-quality and widespread food resources for primates, often being consumed throughout the year (Mendes Pontes, 2000; Nunes, 1998; Spironello, 2001). In this study, Sapotaceae fruit supply was found to be a significant predictor of $A$. belzebuth distribution during LFS at the micro-habitat level at MES. Sapotaceae is one of the most important families in the eastern part of the island (Milliken and Ratter, 1998). Although no single fruit supply can support frugivores in the highly seasonal forest at MES (Mendes Pontes, 2000), it is likely that the pooled fruit supplies of the several high-productive and abundant trees of the Sapotaceae may be a critical resource allowing $A$. belzebuth to overcome overall fruit shortages.

Due to its large body size, costly suspensory locomotion, and highly frugivorous diet, Ateles spp. has high food requirements (Di Fiore et al., 2008; Strier, 1992). This is probably why $A$. belzebuth was more influenced by changes in fruit supply, while the most folivorous A. macconnelli and the omnivorous $C$. olivaceus were less influenced. The lack of relationship between Alouatta palliata and fruit supply has already been reported (Milton et al., 2005). At MES, A. macconnelli seems to track fruit supply only marginally during HFS, when this resource is more abundant. It is likely that the heavy reliance of Alouatta species on leaves, and their energetically conservative lifestyle (Nagy and Milton, 1979; Strier, 1992), could explain this pattern. Similarly, Cebus olivaceus do not need to track changes in fruit supply because it frequently rely on arthropods, an energy-rich and widely available food, and exhibits a widely flexible diet, expanding their dietary breadth when preferred foods are not available (GómezPosada, 2012; Terborgh, 1983). Exploiting alternating food resources is a means of escaping seasonal fruit shortages (van Schaik et al., 1993). Yet, generalist primates may be able to explore immature fruits, while ripe fruit specialists such as $A$. belzebuth do not.

A limitation of this study included the possibility that the set of fruits considered here $\operatorname{did}$ not favour A. macconnelli and $C$. olivaceus, as they were mostly part of $A$. belzebuth diet. Including fruits that were not part of their diets could have overestimated fruit availability for these primates. However, both species often feed on several fruits also eaten by $A$. belzebuth, indicating at least some degree of overlap in their diets (e.g., Mendes Pontes, 1997). Also, the measurement of residual fruit supply was done on the ground rather than in the canopy where primates feed. This approach could be potentially biased by time delay between the appearance of fruits in the canopy and on the ground, or by frugivore consumption (Terborgh, 1983; Zhang and Wang, 1995). However, since I considered the coverage of fruits under canopies rather than fruit number, it is likely that such problems were minimised. Moreover, ground fruit surveys are recognised as providing reliable estimates of fruit availability that are comparable to other methods (Zhang and Wang, 1995). Lastly, the area sampled for fruits actually corresponds to only a small fraction within the home range of primate groups and some of group sightings recorded may have been of primate groups moving between foraging areas well beyond the study transects (Rovero and Struhsaker, 2007). However, I believe that the estimate of fruit supply in each transect was suitable to the comparisons made within this study. The low variance explained by the models tested could also indicate that other non-measured variables influence primate local density.

Overall, the highly frugivorous Ateles belzebuth tends to congregate around areas with high fruit supply during LFS, while other less frugivorous species do not. Seasonal variation in fruit supply is a key component of the variation in the local density of $A$. belzebuth at MES. Examination of the influence of seasonal habitat quality on the distribution of frugivorous primates may improve our understanding on their flexibility to habitat changes, improving our ability to protect and manage primate populations. This consideration is especially useful for the endangered $A$. belzebuth, stressing the importance of fruitrich patches in the forest matrix as critical for this primate during fruit shortages. During such stressful periods, many areas within seasonal forests might not produce enough fruit to meet primate energetic needs, forcing them to congregate in areas with high fruit supplies to meet their nutritional requirements (e.g., Ahumada et al., 1998). Therefore, seasonal changes on fruit supply should be taken into account when designing reserves, managing selective logging and habitat restoration, and defining conservation priorities concerning endangered frugivorous primates in highly seasonal environments.

\section{Acknowledgements}

This manuscript is derived from my doctoral dissertation for the Graduate Programme in Ecology at the Instituto Nacional de Pesquisas da Amazônia (INPA). I am grateful to the staff of the Instituto Chico Mendes de Conservação da Biodiversidade, Programa de Pesquisa em Biodiversidade, and INPA-RR who granted the necessary permits, logistics, and facilities at MES. I wish to thank Fabiana Couto, Sâmya Felizardo and Sara Souza who kindly helped with fruit collection. I am also grateful to my advisor, Renato Cintra, for guidance throughout this study. I am in debt to Celso Morato, Eduardo Venticinque, and William Magnusson for their advice on sampling design and statistics, and to Carlos Cordeiro who kindly helped with the map of the study area. The insightful commentaries and criticisms of Adrian Barnett, Júlio Bicca-Marques, Leonardo Oliveira, Líliam Pinto, Luciano Naka, Marco Pizo, Rossano Mendes Pontes, 
Torbjørn Haugaasen, Wilson Spironello, and an anonymous reviewer, greatly contributed to the improvement of this manuscript. This study was undertaken with the support of the Mohamed bin Zayed Species Conservation Fund, the Conselho Nacional de Desenvolvimento Científico e Tecnológico, Fundação Estadual do Meio Ambiente e Recursos Hídricos de Roraima and Idea Wild.

\section{References}

AHUMADA, JA., STEVENSON, PR. and QUIÑONES, MJ., 1998. Ecological response of spider monkeys to temporal variation in fruit abundance: the importance of flooded forest as a keystone habitat. Primate Conservation, vol. 18, p. 10-14.

CHAPMAN, CA. and CHAPMAN, LJ., 1999. Implications of small scale variation in ecological conditions for the diet and density of red colobus monkeys. Primates, vol. 40, no. 1, p. 215-231. http://dx.doi.org/10.1007/BF02557712. PMid:23179542

CHARNOV, EL., 1976. Optimal foraging, the marginal value theorem. Theoretical Population Biology, vol. 9, no. 2, p. 129-136. http://dx.doi.org/10.1016/0040-5809(76)90040-X. PMid:1273796

CLUTTON-BROCK, TH. and HARVEY, PH., 1977. Primate ecology and social organization. Journal of Zoology, vol. 183, no. 1, p. 1-39. http://dx.doi.org/10.1111/j.1469-7998.1977.tb04171.x.

DI FIORE, A., LINK, A. and DEW, JL., 2008. Diets of wild spider monkeys. In CAMPBELL, CJ. Spider monkeys: behavior, ecology and evolution of the genus Ateles. Cambridge: Cambridge University Press. p. 81-137.

DORMANN, CF., MCPHERSON, JM., ARAÚJO, MB., BIVAND, R., BOLLIGER, J., CARL, G., DAVIES, RG., HIRZEL, A., JETZ, W., KISSLING, WD., KÜHN, I., OHLEMÜLLER, R., PERESNETO, PR., REINEKING, B., SCHRÖDER, B., SCHURR, FM. and WILSON, R., 2007. Methods to account for spatial autocorrelation in the analysis of species distributional data: a review. Ecography, vol. 30, no. 5, p. 609-628. http://dx.doi. org/10.1111/j.2007.0906-7590.05171.x.

FLEMING, TH. and HEITHAUS, ER., 1986. Seasonal foraging behavior of the frugivorous bat Carollia perspicillata. Journal of Mammalogy, vol. 67, no. 4, p. 660-671. http://dx.doi. org/10.2307/1381127.

FOSTER, RB., 1996. The seasonal rhythm of fruitfall on Barro Colorado Island. In LEIGH, EG. Jr., RAND, AS. and WINDSOR, DM. The Ecology of a Tropical Forest. Balboa: Smithsoniam Tropical Research Institute. p. 151-172.

FOX, J. and WEISBERG, S.,2011. An R Companion to Applied Regression. 2nd ed. Los Angeles: SAGE Publications, Inc. 449 p.

GOLDIZEN, AW., TERBORGH, J., CORNEJO, F., PORRAS, DT. and EVANS, R., 1988. Seasonal food shortage, weight loss, and the timing of births in saddle-back tamarins (Saguinus fuscicollis). Journal of Animal Ecology, vol. 57, no. 3, p. 893-901. http://dx.doi.org/10.2307/5099.

GÓMEZ-POSADA, C., 2012. Dieta y comportamiento alimentario de un grupo de mico maicero Cebus apella de acuerdo a la variación en la oferta de frutos y artrópodos, en la Amazonía colombiana. Acta Amazonica, vol. 42, no. 3, p. 363-372. http:// dx.doi.org/10.1590/S0044-59672012000300008.

HANYA, G., KIYONO, M., YAMADA, A., SUZUKI, K., FURUKAWA, M., YOSHIDA, Y. and CHIJIIWA, A., 2006.
Not only annual food abundance but also fallback food quality determines the Japanese macaque density: evidence from seasonal variations in home range size. Primates, vol. 47, no. 3, p. 275-278. http://dx.doi.org/10.1007/s10329-005-0176-2. PMid:16432639

HANYA, G., STEVENSON, P., VAN NOORDWIJK, MV., TE WONG, S., KANAMORI, T., KUZE, N., AIBA, S-I., CHAPMAN, CA. and VAN SCHAIK, C., 2011. Seasonality in fruit availability affects frugivorous primate biomass and species richness. Ecography, vol. 34, no. 6, p. 1009-1017. http://dx.doi. org/10.1111/j.1600-0587.2010.06775.x.

HAUGAASEN, T. and PERES, CA., 2007. Vertebrate responses to fruit production in Amazonian flooded and unflooded forests. Biodiversity and Conservation, vol. 16, no. 14, p. 4165-4190. http://dx.doi.org/10.1007/s10531-007-9217-z.

JANSON, CH. and CHAPMAN, CA., 1999. Resources and primate community structure. In FLEAGLE, JG., JANSON, CH. and REED, KE. Primate Communities. Cambridge: Cambridge University Press. p. 237-267.

KNOTT, CD., 1998. Changes in orangutan caloric intake, energy balance, and ketones in response to fluctuating fruit availability. International Journal of Primatology, vol. 19, no. 6, p. 1061-1079. http://dx.doi.org/10.1023/A:1020330404983.

KRISHNADAS, M., CHANDRASEKHARA, K. and KUMAR, A., 2011. The response of the frugivorous lion-tailed macaque (Macaca silenus) to a period of fruit scarcity. American Journal of Primatology, vol. 73, no. 12, p. 1250-1260. http://dx.doi. org/10.1002/ajp.20997. PMid:21898517

LEIGH, EG. Jr. and WINDSOR, DM., 1996. Forest production and regulation of primary consumers on Barro Colorado Island. In LEIGH, EG. Jr., STANLEY RAND, A. and WINDSOR, DM. The Ecology of a Tropical Forest. Balboa: Smithsoniam Tropical Research Institute. p. 111-122.

LEIGHTON, M. and LEIGHTON, DR., 1982. The relationship of size of feeding aggregate to size of food patch: Howler monkeys (Alouatta palliata) feeding in Trichilia cipo fruit trees on Barro Colorado Island. Biotropica, vol. 14, no. 2, p. 81-90. http://dx.doi. org/10.2307/2387735.

LEVEY, DJ., 1988. Spatial and temporal variation in Costa Rican fruit and fruit-eating bird abundance. Ecological Monographs, vol. 58, no. 4, p. 251-269. http://dx.doi.org/10.2307/1942539.

MARSHALL, AJ. and LEIGHTON, M., 2006. How does food availability limit the population density of white-bearded gibbons? In HOHMANN, G., ROBBINS, MM. and BOESCH, C. Feeding Ecology in Apes and Other Primates. Cambridge: Cambridge University Press. p. 313-335.

MENDES PONTES, AR., 1997. Habitat partitioning among primates in Maracá island, Roraima, northern Brazilian Amazonia. International Journal of Primatology, vol. 18, no. 2, p. 131-157. http://dx.doi.org/10.1023/A:1026364417523.

MENDES PONTES, AR., 1999. Environmental determinants of primate abundance in Maracá Island, Roraima, Brazilian Amazonia. Journal of Zoology, vol. 247, no. 2, p. 189-199.

MENDES PONTES, AR., 2000. Ecology of a mammal community in a seasonally-dry forest in Roraima, Brazilian Amazonia. Cambridge: University of Cambridge. 358 p. Dissertation.

MENDES PONTES, AR., PAULA, MD. and MAGNUSSON, WE., 2012. Low primate diversity and abundance in Northern Amazonia and its implications for conservation. Biotropica, vol. 44, no. 6, p. 834-839. http://dx.doi.org/10.1111/j.1744-7429.2012.00873.x. 
MILLIKEN, W. and RATTER, JA., 1998. The vegetation of the Ilha de Maracá. In MILLIKEN, W. and RATTER, JA. Maracá: the biodiversity and environment of an Amazonian rainforest. Chichester: John Wiley \& Sons Ltd. p. 71-112.

MILTON, K., GIACALONE, J., WRIGHT, SJ. and STOCKMAYER, G., 2005. Do frugivore population fluctuations reflect fruit production? Evidence from Panama. In DEW, JL. and BOUBLI, JP. Tropical Fruits and Frugivores. Dordrecht, The Netherlands: Springer. p. 5-35.

MOSKOVITS, DK., 1985. The behavior and ecology of the two amazonian tortoises Geochelone carbonaria and Geochelone denticulata in northwestern Brasil. Chicago: The University of Chicago. 328 p. Dissertation.

NAGY, KA. and MILTON, K., 1979. Energy metabolism and food consumption by wild howler monkeys (Alouatta palliata). Ecology, vol. 60, no. 3, p. 475-480. http://dx.doi.org/10.2307/1936066.

NUNES, A., 1995. Foraging and ranging patterns in white-bellied spider monkeys. Folia Primatologica (Basel), vol. 65, no. 2, p. 85-99. PMid:8707233.

NUNES, A., 1998. Diet and feeding ecology of Ateles belzebuth belzebuth at Maracá Ecological Station, Roraima, Brazil. Folia Primatologica Basel), vol. 69, no. 2, p. 61-76. http://dx.doi. org/10.1159/000021573. PMid:9583952

PERES, CA., 1994. Primate responses to phenological changes in an Amazonian terra firme forest. Biotropica, vol. 26, no. 1, p. 98-112. http://dx.doi.org/10.2307/2389114.

PERES, CA., 1999. General guidelines for standardizing linetransect surveys of tropical forest primates. Neotropical Primates, vol. 7, no. 1, p. 11-16.

PYKE, GH., PULLIAM, HR. and CHARNOV, EL., 1977. Optimal foraging: a selective review of theory and tests. The Quarterly Review of Biology, vol. 52, no. 2, p. 137-154. http:// dx.doi.org/10.1086/409852.

R DEVELOPMENT CORE TEAM, 2011. $R$ : A language and environment for statistical computing. Version 2.14.0. Vienna, Austria: R Foundation for Statistical Computing. Available from: $<$ http://www.R-project.org/>.

RAMOS PEREIRA, MJ., MARQUES, JT. and PALMEIRIM, JM., 2010. Ecological responses of frugivorous bats to seasonal fluctuation in fruit availability in Amazonian forests. Biotropica, vol. 42 , no. 6 , p. 680-687. http://dx.doi.org/10.1111/j.17447429.2010.00635.x.

ROVERO, F. and STRUHSAKER, TT., 2007. Vegetative predictors of primate abundance: utility and limitations of a fine-scale analysis. American Journal of Primatology, vol. 69, no. 11, p. 1242-1256. http://dx.doi.org/10.1002/ajp.20431. PMid:17358022

SHERMAN, PT. and EASON, PK., 1998. Size determinants in territories with inflexible boundaries: manipulation experiments on white-winged trumpeters' territories. Ecology, vol. 79, no. 4, p. $1147-1159$.
SPIRONELLO, WR., 2001. The brown capuchin monkey (Cebus apella): Ecology and home range requirements in central Amazonia. In BIERREGAARD, RO. Jr., GASCON, C., LOVEJOY, TE. and MESQUITA, R. Lessons from Amazonia: The ecology and conservation of a fragmented forest. New Haven: Yale University Press. p. 271-283.

STEVENSON, P., 2001. The relationship between fruit production and primate abundance in Neotropical communities. Biological Journal of the Linnean Society. Linnean Society of London, vol. 72, no. 1, p. 161-178. http://dx.doi.org/10.1111/j.1095-8312.2001. tb01307.x.

STONE, AI., 2007. Responses of squirrel monkeys to seasonal changes in food availability in an eastern Amazonian forest. American Journal of Primatology, vol. 69, no. 2, p. 142-157. http://dx.doi.org/10.1002/ajp.20335. PMid:17154390

STRIER, KB., 1992. Atelinae adaptations: behavioral strategies and ecological constraints. American Journal of Physical Anthropology, vol. 88, no. 4, p. 515-524. http://dx.doi.org/10.1002/ajpa.1330880407. PMid: 1503122

SYMINGTON, MM., 1988. Environmental deteminants of population densities in Ateles. Primate Conservation, vol. 9, p. 74-79.

TERBORGH, J., 1983. Five new world primates. Princeton, NJ: Princeton University Press. 260 p.

TERBORGH, J., 1986. Community aspects of frugivory in tropical forests. In ESTRADA, A. and FLEMING, TH. Frugivores and Seed Dispersal. Dordrecht: Dr W. Junk Publishers. p. 371-384.

VAN SCHAIK, CP., TERBORGH, JW. and WRIGHT, SJ., 1993. The phenology of tropical forests: adaptive significance and consequences for primary consumers. Annual Review of Ecology and Systematics, vol. 24, p. 353-377. http://www.jstor. org/stable/2097183.

VEDDER, AL., 1984. Movement patterns of a group of freeranging mountain gorillas (Gorilla gorilla beringei) and their relation to food availability. American Journal of Primatology, vol. 7, no. 2, p. 73-88. http://dx.doi.org/10.1002/ajp.1350070202.

VOGEL, ER., KNOTT, CD., CROWLEY, BE., BLAKELY, MD., LARSEN, MD. and DOMINY, NJ., 2012. Bornean orangutans on the brink of protein bankruptcy. Biology Letters, vol. 8, no. 3, p. 333-336. http://dx.doi.org/10.1098/rsbl.2011.1040. PMid:22171019

WALLACE, RB., 2005. Seasonal variations in diet and foraging behavior of Ateles chamek in a southern Amazonian tropical forest. International Journal of Primatology, vol. 26, no. 5, p. 1053-1075. http://dx.doi.org/10.1007/s10764-005-6458-4.

ZHANG, S-Y. and WANG, L-X., 1995. Comparison of three fruit census methods in French Guiana. Journal of Tropical Ecology, vol. 11, no. 2, p. 281-294. http://dx.doi.org/10.1017/ S0266467400008750. 